\title{
Perbedaan Kadar Vitamin D pada Wanita Usia Reproduksi Tidak Hamil dan Wanita Hamil Trimester Pertama
}

\author{
Mochamad Rizkar Arev Sukarsa, Radiastomo Samekta Budi, \\ Benny Hasan Purwara, Hanom Husni Syam, Johanes Cornelius Mose, \\ Yudi Mulyana Hidayat, R.M Sonny Sasotya \\ Departemen Obstetri dan Ginekologi Fakultas Kedokteran Universitas Padjadjaran \\ Rumah Sakit Dr. Hasan Sadikin Bandung \\ Korespondensi: Mochamad Rizkar Arev Sukarsa, email: morizarev@gmail.com
}

\begin{abstract}
Abstrak
Tujuan: Penelitian ini untuk mengetahui perbedaan kadar vitamin D pada wanita usia reproduksi tidak hamil dan wanita hamil trimester pertama.

Metode: Penelitian ini merupakan penelitian analitik observasional dengan metode rancangan Comparative Cross Sectional yaitu membandingkan kadar vitamin D pada dua kelompok yaitu wanita usia reproduksi tidak hamil dan wanita hamil trimester pertama. Subjek penelitian yaitu wanita usia reproduksi (18-35 tahun) tidak hamil dan bertempat tinggal di kota Bandung dengan wanita dengan usia kehamilan trimester pertama yang memenuhi kriteria inklusi penelitian $(\mathrm{n}=60)$. Pada kedua kelompok dilakukan pemeriksaan kadar vitamin $\mathrm{D}$ kemudian diperiksa dengan metode Electro-chemiluminescence immunoassay (ECLIA). Penelitian ini dilakukan di RSUP Dr. Hasan Sadikin Bandung pada bulan Februari-April 2018.

Hasil: Hasil penelitian menunjukkan kadar vitamin D rata-rata pada kelompok wanita usia reproduksi tidak hamil adalah 18,73 $(6,93) \mathrm{ng} / \mathrm{mL}$, sementara pada kelompok wanita hamil trimester pertama yaitu $13,87(4,04) \mathrm{ng} / \mathrm{mL}$. Perbedaan kadar rata-rata vitamin D pada kedua kelompok tersebut bermakna dengan nilai $\mathrm{p}<0,001$

Simpulan: Kadar vitamin D pada kelompok wanita hamil trimester pertama lebih rendah dibandingkan dengan kelompok usia reproduksi tidak hamil
\end{abstract}

Kata kunci: Vitamin D, wanita usia reproduksi tidak hamil, wanita hamil trimester pertama

\section{Differences of vitamin D Level in Non-Pregnant Reproductive Age Women and First Trimester Pregnant Women}

\begin{abstract}
Objective: This research aims to compare differences in vitamin D levels in the group of non pregnant women of reproductive age and group of first trimester pregnant women.

Method: This type of research is an observational analytic study with Comparative Cross Sectional design method that is comparing vitamin D levels in two groups: non pregnant women of reproductive age and first trimester pregnant women. Subjects of the study were women of reproductive age (18-35 years) who were not pregnant and lived in Bandung with women with first trimester gestational age who fulfilled the inclusion criteria $(n=60)$. In both groups examined vitamin D levels and then examined by Electro-chemiluminescence immunoassay (ECLIA) method. This research was conducted at Hasan Sadikin Hospital Bandung in February-April 2018

Results: The results showed that the average vitamin D level in the non pregnant women of reproductive age group was 18.73 (6.93) $\mathrm{ng} / \mathrm{mL}$, while in the first trimester pregnant women group was 13.87 (4.04) $\mathrm{ng} / \mathrm{mL}$. The difference in mean vitamin D levels in both groups was significant with $p<0.001$

Conclusion: Levels of vitamin D in the group of first trimester pregnant women are lower than the group of non pregnant women of reproductive
\end{abstract}

Keywords: Vitamin D, women of reproductive age not pregnant, first trimester pregnant women 


\section{Pendahuluan}

Indonesia adalah negara tropis yang sepanjang tahun disinari matahari. Penelitian yang telah dilakukan di Indonesia dan Malaysia tahun 2015 pada 504 wanita usia reproduksi yang berusia 18-40 tahun, menemukan rata rata konsentrasi serum $25(\mathrm{OH}) \mathrm{D}$ adalah $48 \mathrm{nmol} / \mathrm{L}$ dengan prevalensi defisiensi vitamin D sebesar 63\%.,2 Beberapa tahun belakangan jumlah penelitian eksperimental, observasional, dan intervensional telah menunjukkan adanya peran preventif vitamin $\mathrm{D}$ dalam fungsi fisiologis skeletal dan nonskeletal. ${ }^{3}$ Sumber utama vitamin D (80-90\%) berasal dari kulit yang diinduksi oleh sinar ultraviolet, sisanya berasal dari diet dan atau suplemen vitamin D yang terdistribusi di beberapa jaringan seperti skeletal, kelenjar paratiroid, dan jaringan sistem reproduksi. ${ }^{4-6}$

Proses kehamilan dan persalinan menyebabkan terjadinya kerusakan otot panggul yaitu pada proses kehamilan terjadi peregangan beberapa otot panggul. Kecepatan perbaikan otot panggul ini dipengaruhi oleh berbagai macam penyebab dan salah satunya yaitu kadar vitamin D pada usia reproduksi maupun pada kehamilan trimester pertama. ${ }^{2}$ Pemberian suplementasi vitamin D pada wanita usia reproduksi tidak hamil yang tidak hamil dan wanita hamil trimester pertama tidak rutin diberikan di Indonesia. Nilai batasan kadar vitamin D normal pada wanita usia reproduksi tidak hamil yang tidak hamil dan wanita hamil trimester pertama di Indonesia sendiri belum diketahui. Beberapa faktor yang mempengaruhi terjadinya defisiensi vitamin D pada wanita usia reproduksi tidak hamil dan pada wanita hamil trimester pertama yaitu meliputi perubahan fungsi organ yang terlibat dalam proses sintesis $25(\mathrm{OH}) \mathrm{D}$ seperti kulit, hati, ginjal, dan usus, gaya hidup yang cenderung menghindari sinar matahari, penggunaan tabir surya dan rendahnya asupan makanan yang mengandung vitamin
D. Defisiensi vitamin ini dapat diatasi dengan meningkatkan sintesis vitamin D melalui fortifikasi, suplementasi vitamin D dan melalui paparan sinar matahari. ${ }^{7}$

Faktor lain yang mempengaruhi kadar vitamin D pada wanita usia reproduksi tidak hamil dibandingkan pada wanita hamil trimester pertama yaitu indeks massa tubuh yang meningkat. Pada wanita obesitas dengan indeks massa tubuh $>30 \mathrm{~kg} / \mathrm{m}^{2}$ berhubungan dengan kadar serum vitamin $D$ binding protein (VDBP) yang lebih tinggi dan konsentrasi 25(OH)D bebas yang lebih rendah pada serum dibandingkan dengan wanita dengan berat yang normal. $25(\mathrm{OH}) \mathrm{D}$ dan $1,25(\mathrm{OH})_{2} \mathrm{D}$ keduanya berikatan dengan DBP $(85-88 \%)$ dan albumin $(12-15 \%)$ di dalam darah, dengan hanya sebagian kecil dalam bentuk bebas. ${ }^{8}$ Konsentrasi DBP yang lebih tinggi pada wanita obesitas dijelaskan karena adanya gangguan metabolisme estrogen sehingga kadar estrogen bebas yang lebih tinggi pada obesitas dapat memberikan efek pada produksi VDBP di liver. ${ }^{9}$

Pengaruh Vitamin D pada kekuatan otot dan fungsi otot telah ditunjukkan pada berbagai penelitian terhadap otot lurik hewan maupun manusia. Kelemahan otot dasar panggul dapat bermanifestasi klinis pada gejala-gejala disfungsi dasar panggul, antara lain inkontinensia urin, inkontinensia fekal, dan prolaps organ panggul. Dalam sebuah penelitian tentang Vitamin D yang dilakukan Normala tahun 2017 dikatakan bahwa sekitar 38,60\% termasuk golongan defisiensi berat $(<10 \mathrm{ng} / \mathrm{mL}), \quad 56,81 \%$ defisiensi sedang (10-19.9 ng/mL), dan $4,54 \%$ defisiensi ringan (20-29.9), dan berpengaruh terhadap prolaps uteri. Hal ini menunjukan tingginya angka defisiensi vitamin $\mathrm{D}$ pada wanita usia reproduktif. ${ }^{10}$ Hubungan klinis defisiensi vitamin D dan gangguan dasar panggul diduga akibat berkurangnya massa otot dan kekuatan otot lurik seluruh tubuh, termasuk otot lurik dasar panggul. ${ }^{11}$ Chaliha dkk menemukan bahwa fungsi otot dasar 
panggul membaik setelah 6 bulan pasca persalinan pervaginam. Kerusakan anatomis yang terjadi salah satunya adalah avulsi otot levator ani. ${ }^{12}$ Akhdasari dkk mendapatkan bahwa tidak terdapat perbedaan tonus basal dan kontraksi maksimal levator ani antara kelompok primipara yang mengalami avulsi dan tidak mengalami avulsi. ${ }^{13-16}$

Penelitian tentang penyebab terjadinya defisiensi vitamin D pada wanita usia reproduksi tidak hamil dan wanita hamil trimester pertama belum pernah dilakukan di Indonesia sehingga hal ini merupakan masalah yang menarik untuk diteliti. Tujuan penelitian ini adalah untuk melihat perbedaan kadar vitamin D serta peranan pemeriksaan kadar vitamin D pada wanita usia reproduksi tidak hamil dan pada wanita usia hamil trimester pertama yang bertujuan mencegah terjadinya defisiensi kadar vitamin D sehingga dapat mencegah terjadinya peningkatan angka kejadian preeklamsia, diabetes mellitus pada kehamilan, ${ }^{17}$ kelemahan otot dasar panggul dan menekan angka kejadian kanker pada wanita usia reproduksi tidak hamil dan wanita hamil.

\section{Metode}

Penelitian ini merupakan penelitian analitik observasional dengan rancangan Comparative cross sectional yaitu membandingkan kadar vitamin D pada dua kelompok yaitu wanita usia reproduksi tidak hamil dan wanita hamil trimester pertama. ${ }^{18}$ Subjek penelitian dipilih baik untuk wanita usia reproduksi tidak hamil maupun wanita hamil trimester pertama terhadap semua subjek diperiksa data dasar mengenai Usia, Indeks Massa Tubuh (IMT), paparan sinar matahari, jumlah kalori makanan sehingga luaran (outcome) yang dinilai adalah kadar vitamin D.

Penarikan sampel dilakukan secara consecutive sampling. Pada penelitian ini desain yang digunakan adalah desain khusus, penelitiannya analitis kategorik numerik tidak berpasangan. Maka penentuan besar sampel, dilakukan berdasarkan perhitungan statistik dengan menetapkan taraf kepercayaan 95\% dan kuasa uji power test $80 \%$. Dengan menggunakan rumus penentuan besar sampel untuk penelitian analitis kategorik numerik tidak berpasangan diperlukan jumlah sampel untuk kelompok wanita usia reproduksi tidak hamil sebanyak 30 orang dan wanita hamil trimester pertama sebanyak 30 orang. Sehingga total jumlah sampel adalah 60 orang.

Dari data yang terkumpul selanjutnya dianalisis secara deskriptif dan analitik. Kemaknaan hasil uji ditentukan berdasarkan nilai $\mathrm{p}<0,05$. Data yang diperoleh dicatat dalam formulir khusus kemudian diolah melalui program SPSS versi 24.0. ${ }^{19}$

\section{Hasil}

Karakteristik subjek penelitian untuk melihat perbedaan kadar vitamin D pada wanita usia reproduksi tidak hamil dan wanita hamil trimester pertama dapat dilihat pada Tabel 1.

Tabel 1 menunjukkan karakteristik subjek penelitian berdasarkan usia, indeks massa tubuh, lama paparan sinar matahari dan jumlah kalori makan antara kelompok wanita usia reproduksi tidak hamil dan wanita hamil trimester pertama. Berdasarkan karakteristik usia diketahui nilai rerata dan standar deviasi untuk kelompok wanita usia reproduksi tidak hamil yaitu sebesar 23,9 (4,6) tahun dan kelompok wanita hamil trimester pertama sebesar 25,7 $(4,6)$ tahun. Karakteristik indeks massa tubuh diketahui nilai rerata dan standar deviasi untuk kelompok wanita usia reproduksi tidak hamil yaitu sebesar 22,6 $(2,8) \mathrm{kg} / \mathrm{m}^{2}$ dan kelompok wanita hamil trimester pertama sebesar 23,8 $(3,1) \mathrm{kg} / \mathrm{m}^{2}$. Karakteristik lama paparan sinar matahari diketahui nilai rerata dan standar deviasi untuk kelompok wanita usia reproduksi tidak hamil yaitu sebesar 
Tabel 1 Karakteristik Subjek Penelitian

\begin{tabular}{|c|c|c|c|}
\hline \multirow[b]{2}{*}{ Karakteristik } & \multicolumn{2}{|c|}{ Kelompok } & \multirow[b]{2}{*}{ Nilai $\left.p^{*}\right)$} \\
\hline & $\begin{array}{c}\text { Usia Reproduksi } \\
\text { Tidak Hamil } \\
(n=30)\end{array}$ & $\begin{array}{c}\text { Hamil Trimester } \\
\text { Pertama } \\
(\mathbf{n}=\mathbf{3 0})\end{array}$ & \\
\hline \multicolumn{4}{|l|}{ Usia } \\
\hline Rata-rata (SD) & $23,9(4,6)$ & $25,7(4,6)$ & $0,153^{*}$ \\
\hline Median & 21,5 & 26,5 & \\
\hline Rentang & $19-34$ & $19-34$ & \\
\hline \multicolumn{4}{|l|}{ Indeks Massa Tubuh $\left(\mathrm{kg} / \mathrm{m}^{2}\right)$} \\
\hline Rata-rata (SD) & $22,6(2,8)$ & $23,8(3,1)$ & $0,101^{* *}$ \\
\hline Median & 21,9 & 24,4 & \\
\hline Rentang & $18,3-29,9$ & $18,7-29,5$ & \\
\hline \multicolumn{4}{|l|}{ Kalori Asupan Makan (kkal) } \\
\hline Rata-rata (SD) & $2053,3(179,5)$ & $2223,3(170,6)$ & $<0,001^{* *}$ \\
\hline Median & 2050 & 2250 & \\
\hline Rentang & $1700-2500$ & $1800-2500$ & \\
\hline \multicolumn{4}{|c|}{$\begin{array}{l}\text { Lama Paparan Sinar Matahari } \\
\text { (menit) }\end{array}$} \\
\hline Rata-rata (SD) & $18,0(4,1)$ & $17,7(3,4)$ & $0,736^{*}$ \\
\hline Median & 20 & 17,5 & \\
\hline Rentang & $10-25$ & $10-25$ & \\
\hline
\end{tabular}

Keterangan: *) dihitung berdasarkan uji Mann-Whitney; **) uji t tidak berpasangan. Bermakna bila $p<0,05$.

$18,0(4,1)$ menit dan kelompok wanita hamil trimester pertama sebesar $17,7(3,4)$ menit. Berdasarkan karakteristik jumlah asupan kalori makanan diketahui nilai rerata dan standar deviasi untuk kelompok wanita usia reproduksi tidak hamil yaitu sebesar 2053,3 $(179,5)$ kkal dan kelompok wanita hamil trimester pertama sebesar 2223,3(170,6) kkal. Perhitungan jumlah kalori dilakukan dengan pengisian kuesioner Food recall 24 jam dan Food frequency questionnaire

Tampak hasil uji statistik gambaran karakteristik kedua kelompok yang meliputi usia, Indeks Massa Tubuh dan lama paparan sinar matahari tidak menunjukkan ada perbedaan yang bermakna $(\mathrm{p}>0,05)$; sedangkan untuk jumlah kalori asupan makan pada kelompok hamil trimester pertama lebih tinggi bila dibandingkan dengan kelompok usia reproduksi, dan perbedaannya secara statistik bermakna $(p<0,05)$. Karena jumlah kalori pada kedua kelompok penelitian menunjukkan ada perbedaan, maka untuk perhitungan lebih lanjut dijadikan sebagai variabel perancu.

Tabel 2 menjelaskan tentang perbedaan kadar vitamin D dan status kadar vitamin D pada kedua kelompok penelitian yaitu wanita usia reproduksi tidak hamil dan wanita hamil trimester pertama. Untuk variabel kadar vitamin D pada kelompok wanita usia reproduksi tidak hamil memiliki nilai ratarata $18,73(6,93) \mathrm{ng} / \mathrm{mL}$, sedangkan pada kelompok wanita hamil trimester pertama memiliki nilai rata-rata $13,87(4,04) \mathrm{ng} / \mathrm{mL}$.

Dari hasil penelitian diperoleh nilai ratarata kadar vitamin D sebelum dan sesudah di adjusted dengan jumlah kalori asupan makan maka kadar vitamin D pada wanita usia reproduksi tidak hamil lebih tinggi dibandingkan dengan kelompok wanita hamil trimester pertama. Untuk data numerik diuji dengan analisis kovarians dan dari hasil uji statistika pada kedua kelompok penelitian 
Tabel 2 Perbedaan Kadar Vitamin D pada Wanita Usia Reproduksi Tidak Hamil dan Wanita Hamil Trimester Pertama

\begin{tabular}{|c|c|c|c|}
\hline \multirow[b]{2}{*}{ Variabel } & \multicolumn{2}{|c|}{ Kelompok } & \multirow[b]{2}{*}{ Nilai p } \\
\hline & $\begin{array}{c}\text { Usia Reproduksi } \\
\text { Tidak Hamil } \\
(\mathbf{n}=\mathbf{3 0})\end{array}$ & $\begin{array}{c}\text { Hamil Trimester } \\
\text { Pertama } \\
(\mathbf{n}=\mathbf{3 0})\end{array}$ & \\
\hline \multicolumn{4}{|l|}{ Kadar vitamin D (ng/ml) } \\
\hline Rata-rata (SD) & $18,73(6,93)$ & $13,87(4,04)$ & $0,004^{*}$ \\
\hline Median & 17,58 & 12,34 & \\
\hline Rentang & $10,39-36,26$ & $8,48-24,65$ & \\
\hline \multicolumn{4}{|c|}{ Kadar vitamin D setelah di adjusted jumlah } \\
\hline \multicolumn{4}{|c|}{ kalori asupan makan : } \\
\hline Rata-rata (SE) & $19,71(1,03)$ & $12,89(1,03)$ & $<0,001^{* *}$ \\
\hline Interval konfidensi 95\% & $17,64-21,78$ & $10,82-14,96$ & \\
\hline \multicolumn{4}{|l|}{ Status Kadar Vitamin D : } \\
\hline Defisiensi $(<12)$ & 5 & 14 & \\
\hline Insufisiensi (12-20) & 11 & 13 & $0,003^{* * *}$ \\
\hline Suffisiensi $(>20)$ & 14 & 3 & \\
\hline
\end{tabular}

Keterangan : *) berdasarkan uji Mann-Whitney;

**) berdasarkan analisis kovarians

***) Uji Chi-kuadrat. Bermakna bila $p<0,05$.

memiliki nilai $\mathrm{p}$ lebih kecil daripada 0,05 (nilai $\mathrm{p}<0,001$ ) yang berarti kedua kelompok signifikan atau bermakna secara statistik. Dengan demikian dapat dikatakan bahwa terdapat perbedaan rerata bermakna antara kedua kelompok penelitian.

Selanjutnya berdasarkan status kadar vitamin D pada wanita usia reproduksi tidak hamil sebagian besar yaitu sebanyak $46,7 \%$ mengalami kecukupan suffisiensi vitamin D sedangkan pada wanita hamil trimester pertama sebagian besar yaitu sebanyak $46,7 \%$ mengalami defisiensi vitamin D. Untuk lebih jelasnya perbedaan kadar vitamin D pada kedua kelompok disajikan pada gambar 1 .

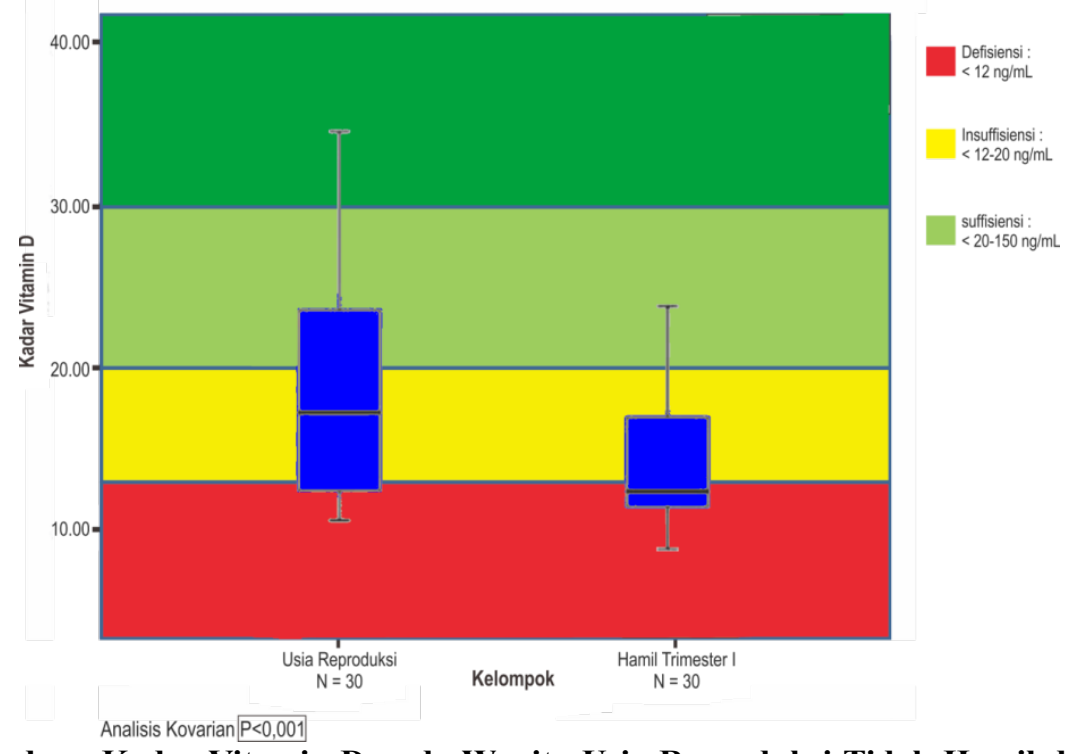

Gambar 1 Perbedaan Kadar Vitamin D pada Wanita Usia Reproduksi Tidak Hamil dan Wanita Hamil Trimester Pertama 


\section{Pembahasan}

Karakteristik subjek penelitian yang dibandingkan pada penelitian ini adalah usia, Indeks Massa Tubuh, paparan sinar matahari dan jumlah kalori asupan makan.

Hal ini berdasarkan dugaan bahwa keempat faktor tersebut dapat menjadi faktor perancu terhadap hasil penelitian ini. Berdasarkan hasil penelitian yang telah dipaparkan di atas didapatkan bahwa tidak ada perbedaan bermakna pada karakteristik subjek penelitian, yaitu usia pasien $(\mathrm{p}=0,153)$, Indeks Massa Tubuh $(\mathrm{p}=0,101)$ dan lama paparan sinar matahari $(\mathrm{p}=0,736)$ sedangkan jumlah kalori asupan makan $(\mathrm{p}<0,001)$.

Karakteristik jumlah kalori asupan makan pada subjek penelitian ini sesuai dengan dengan penelitian yang dilakukan Mottola dkk yang menyarankan agar wanita usia reproduksi tidak hamil memiliki asupan kalori harian yaitu 1.800-2.000 kkal jika memiliki aktivitas harian ringan dan 2.0002.200 jika aktivitas harian sedang-berat. Pada wanita hamil trimester pertama kebutuhan asupan kalori harian meningkat yaitu bertambah 150-200 kkal. Hal ini disebabkan oleh kebutuhan pembentukan janin yang pesat. $^{20}$ Kadar rata-rata vitamin D pada kelompok wanita usia reproduksi tidak hamil pada penelitian ini didapatkan lebih tinggi secara bermakna dibandingkan kelompok wanita hamil trimester pertama.

Keseluruhan subjek pada penelitian ini memiliki kadar vitamin D dibawah normal $(<30 \mathrm{ng} / \mathrm{mL})$. Pada penelitian di Indonesia dan Malaysia yang dilakukan Yosephin dkk., pada 504 wanita usia subur (WUS) berusia 18-40 tahun menemukan kadar konsentrasi serum 25-hidroksi-vitamin $\mathrm{D}_{3}$ adalah 48ng/ $\mathrm{mL}$ dengan prevalensi defisiensi vitamin $\mathrm{D}$ sebesar 63\%. Sebanyak 63\% WUS di Jakarta berusia 18-40 tahun di Jakarta mengalami defisiensi vitamin $\mathrm{D}$ dengan rata-rata kadar konsentrasi 25-hidroksi-vitamin $\mathrm{D}_{3}$ adalah 19,2 ng/mL. ${ }^{1}$ Berdasarkan uraian penelitan tersebut didapatkan bahwa defisiensi vitamin $\mathrm{D}$ dapat disebabkan gaya hidup yang cenderung menghindari paparan sinar matahari, penggunaan tabir surya dan asupan makanan yang rendah kadar vitamin $D$.

Orang-orang yang tinggal dekat garis khatulistiwa yang terpapar sinar matahari tanpa menggunakan pelindung sejenis tabir surya mempunyai kadar konsentrasi 25-hidroksi-vitamin $\mathrm{D}_{3}$ diatas 30ng/mL. ${ }^{1,21}$

Studi observasional menyatakan bahwa defisiensi vitamin D menjadi faktor dalam patofisiologi dari beberapa jenis kanker, penyakit kardiovaskular, hipertensi, preeklamsia, diabetes dan morbiditas pada kehamilan. ${ }^{22}$ Didapatkan data dari tahun 2005-2006 survei NHANES menunjukkan bahwa $69 \%$ dari wanita hamil dan $78 \%$ dari wanita usia reproduksi tidak hamil pada perempuan Amerika Serikat memiliki kadar 25-hidroksi-vitamin $\mathrm{D}_{3}<30 \mathrm{ng} / \mathrm{mL}$.

Pada kehamilan, plasenta adalah sumber ekstra renal dari calcitriol (1,25-dihidroksivitamin D). ${ }^{23}$ Penelitian sebelumnya juga menyebutkan bahwa defisiensi vitamin D pada wanita hamil berhubungan dengan risiko persalina seksio sesarea. Risiko seksio sesarea emergensi meningkat dua kali lipat pada wanita hamil yang mengalami partus lama disertai dengan defisiensi vitamin D. ${ }^{24}$

Namun, De-Regil dkk. menunjukkan bahwa pemberian suplementasi vitamin D3 pada wanita hamil tidak bermanfaat dalam mengurangi kejadian persalinan seksio sesarea. ${ }^{25}$ Defisiensi pada ibu hamil juga memberikan dampak buruk terhadap hasil persalinan. Risiko yang dialami oleh neonatus pada ibu hamil defisiensi vitamin D antara lain: pertumbuhan janin terhambat, eksim, riketsia dan hipokalsemia. ${ }^{22}$ Satu alasan yang mungkin untuk rendahnya $25(\mathrm{OH}) \mathrm{D}$ pada wanita hamil trimester pertama adalah asupan vitamin D yang rendah. Pada survei asupan makanan nasional yang dilakukan di Swedia oleh Riksmaten pada tahun 2010-2011, asupan makanan vitamin D pada wanita 
pada kelompok usia 18-30 tahun dan 3144 tahun adalah 5.2 dan $6.2 \mu \mathrm{g} /$ hari, secara berurutan. ${ }^{26} 25(\mathrm{OH}) \mathrm{D}$ yang lebih rendah pada populasi wanita hamil trimester pertama telah dijelaskan oleh model dilusi. Vitamin $\mathrm{D}_{3}$ dan metabolitnya terlokalisasi pada droplet lipid di adiposit. ${ }^{26}$

Suplementasi vitamin D pada ibu hamil disarankan untuk memperbaiki metabolisme kalsium janin, status muskular janin dan kadar vitamin D ibu. Dosis maternal dapat diberikan hingga $4000 \mathrm{IU} /$ hari. ${ }^{22}$ Penelitian oleh Wagner dkk. menunjukkan bahwa pemberian suplementasi vitamin $\mathrm{D}$ saat hamil secara langsung berhubungan dengan perkembangan janin yang lebih baik. ${ }^{27}$ Penelitian ini memiliki keterbatasan.

Pertama, penelitian ini bersifat cross sectional sehingga tidak dapat disimpulkan tentang penyebab perbedaan kadar vitamin D pada kedua grup penelitian. Kedua, data status vitamin D rata-rata pada populasi di Asia Tenggara masih sangat terbatas sehingga tidak didapatkan nilai acuan kadar rata-rata vitamin D pada orang Indonesia. Penelitian ini diharapkan dapat dijadikan sebagai data dasar serta acuan dalam mendeteksi terjadinya kekurangan vitamin D pada wanita usia reproduksi tidak hamil dan wanita hamil trimester pertama sehingga dapat membantu menurunkan angka morbiditas dan mortalitas yang dikarenakan komplikasi seperti preeklamsia, diabetes pada kehamilan, berat badan lahir rendah pada bayi, kehamilan prematur, kelemahan otot dasar panggul dan penyakit infeksi.

\section{Daftar Pustaka}

1. Yosephin B, Khomsan A, Briawan D, Rimbawan R. Vitamin D plus calcium supplementation increased serum 25 $(\mathrm{OH}) \mathrm{D}$ on reproductive age women workers. Asian Pacific Journal of Tropical Disease. 2015;5(11):877-80.

2. Aleyasin A, Hosseini MA, Mahdavi A,
Safdarian L, Fallahi P, Mohajeri MR, et al. Predictive value of the level of vitamin $\mathrm{D}$ in follicular fluid on the outcome of assisted reproductive technology. European Journal of Obstetrics and Gynecology and Reproductive Biology. 2011;159(1):132-7.

3. Holick MF. The vitamin D deficiency pandemic: a forgotten hormone important for health. Public health reviews. 2010;32(1):267.

4. Grundmann M, von Versen-Höynck F. Vitamin D-roles in women's reproductive health? Reproductive biology and endocrinology. 2011;9(1):146.

5. Lerchbaum E, Obermayer-Pietsch B. Mechanisms in endocrinology: Vitamin $\mathrm{D}$ and fertility: a systematic review. European Journal of Endocrinology. 2012;166(5):765-78.

6. Luk J, Torrealday S, Neal Perry G, Pal L. Relevance of vitamin D in reproduction. Human reproduction. 2012;27(10):3015-27.

7. Bolland MJ, Grey AB, Ames RW, Horne AM, Mason BH, Wattie DJ, et al. Age, gender, and weight related effects on levels of 25 hydroxyvitamin $\mathrm{D}$ are not mediated by vitamin $\mathrm{D}$ binding protein. Clinical endocrinology. 2007;67(2):259-64.

8. BIKLE DD, GEE E, HALLORAN B, KOWALSKI MA, RYZEN E, HADDAD JG. Assessment of the free fraction of 25-hydroxyvitamin $\mathrm{D}$ in serum and its regulation by albumin and the vitamin D-binding protein. The Journal of Clinical Endocrinology \& Metabolism. 1986;63(4):954-9.

9. Pasquali R. Obesity and androgens: facts and perspectives. Fertility and sterility. 2006;85(5):1319-40.

10. Normala A. Perbandingan kadar 25-hidroksi vitamin D3 serum antara penderita prolaps organ panggul dengan non prolaps organ panggul pada perempuan menopause [thesis]: 
universitas padjadjaran; 2017.

11. Aydogmus S, Kelekci S, Aydogmus H, Demir M, Yilmaz B, Sutcu R. Association of antepartum vitamin D levels with postpartum pelvic floor muscle strength and symptoms. International urogynecology journal. 2015;26(8):1179-84.

12. Allen R, Hosker G, Smith A, Warrell D. Pelvic floor damage and childbirth: a neurophysiological study. BJOG. 1990;97(9):770-9.

13. Smith K, Drutz H. The Effect of Pregnancy and Childbirth on the Lower Urinary Tract and Pelvic Floor. In: Drutz H, Herschorn S, Diamant N, penyunting. Female Pelvic Med Reconstr Surg. edisi. London: Springer-Verlag London; 2003. hlm. 69-78.

14. Chaliha C, Soligo M, Khullar V. Caesarean Section is Protective against Stress Incontinence: An Analysis of Women with Multiple Deliveries. British Journal of Obstetric and Gynecology. 2004;111:754-5.

15. Allen RE, Hosker GL, Smith ARB, Warell DW. Pelvic Floor Damage and Childbirth; a Neurophysiological Study. British Journal of Obstetric and Gynecology. 1990;97:770-9.

16. Akhdasari F. Perbandingan tonus basal dan kontraksi maksimal levator ani antara primipara yang mengalami dan tidak mengalami avulsi. Bandung: Universitas Padjadjaran; 2014.

17. Zhang MX, Pan GT, Guo JF, Li BY, Qin LQ, Zhang ZL. Vitamin D Deficiency Increases the Risk of Gestational Diabetes Mellitus: A Meta-Analysis of Observational Studies. Nutrients. 2015;7(10):8366-75.

18. Levy PS, Lemeshow S. Sampling of populations: methods and applications: John Wiley \& Sons; 2013. Number of Page hlm.

19. Field A. Discovering statistics using IBM
SPSS statistics: sage; 2013. Number of Page hlm.

20. Mottola MF, Giroux I, Gratton R, Hammond J-A, Hanley A, Harris S, et al. Nutrition and exercise prevent excess weight gain in overweight pregnant women. Medicine and science in sports and exercise. 2010;42(2):265.

21. Green T, Skeaff C, Rockell J, Venn B, Lambert A, Todd J, et al. Vitamin D status and its association with parathyroid hormone concentrations in women of child-bearing age living in Jakarta and Kuala Lumpur. European journal of clinical nutrition. 2008;62(3):373.

22. Elsori DH, Hammoud MS. Vitamin D deficiency in mothers, neonates and children. The Journal of steroid biochemistry and molecular biology. 2018;175:195-9.

23. Ginde AA, Sullivan AF, Mansbach JM, Camargo CA. Vitamin D insufficiency in pregnant and nonpregnant women of childbearing age in the United States. American Journal of Obstetrics \& Gynecology. 2010;202(5):436. e1-. e8.

24. Scholl TO, Chen X, Stein P. Maternal vitamin $\mathrm{D}$ status and delivery by cesarean. Nutrients. 2012;4(4):319-30.

25. De-Regil LM, Palacios C, Ansary A, Kulier R, Pena-Rosas JP. Vitamin D supplementation for women during pregnancy. The Cochrane database of systematic reviews. 2012(2): Cd008873.

26. Karlsson T. Vitamin D in women of reproductive age and during pregnancyFocus on intake, status and adiposity 2013. Number of Page hlm.

27. Wagner CL, McNeil RB, Johnson DD, Hulsey TC, Ebeling M, Robinson $\mathrm{C}$, et al. Health characteristics and outcomes of two randomized vitamin D supplementation trials during pregnancy: a combined analysis. The Journal of steroid biochemistry and molecular biology. 2013;136:313-20. 